\section{Traditional Eye Medicines in Tanzania: Products, Health Risk Awareness and Safety Evaluation}

\section{Abstract}

Background information: Eyes are delicate sensory organs necessary to give comfort for our life. Eye treatment requires special attention to avoid serious medical problems including blindness. Traditional eye medicines (TEM) are in most cases of unknown chemical nature, and vital parameters like sterility and $\mathrm{pH}$ are not controlled subjecting users to partial or total vision disability.

Aims: This work was aimed at systematic presentation of previously documented Tanzania TEM, documenting similar products, assessment of awareness of TEM health risks and safety evaluation.

Methodology: Data from previous studies was obtained from published journal articles and books. Ethno pharmacological study was conducted in Kigoma district by interviewing traditional healers and knowledgeable people guided by the structured questionnaire. Awareness on TEM associated health risks and later Safety evaluation was done based on $\mathrm{pH}$ values determination and culturing of lizard droppings on three culture media.

Results: TEM reported in this study are 80 medicinal plants belonging to 42 families, animal excreta and unrefined salt. Among the interviewees, $65 \%$ were unaware of health risks associated with the use of TEM. The $\mathrm{pH}$ of the tested product was ranging between 2.5 and 6.57. Lizard droppings showed contamination of Gram positive and Gram negative bacteria and fungi.

Keywords: Ethnopharmacology; Traditional eye medicine; Kigoma district; Tanzania

\section{Sheila Maregesi $\mathbf{M}^{1}$, Bakari Kauke², Godeliver Kagashe ${ }^{1}$ and Reuben Kaali ${ }^{2}$}

1 Pharmacognosy Department, School of Pharmacy, Muhimbili University College of Health and Allied Sciences, Dar Es Salaam, Tanzania

2 Faculty of Pharmacy, St John's University of Tanzania, Dodoma, Tanzania

\section{Corresponding author: Sheila Maregesi}

” smaregesi@hotmail.com

Pharmacognosy Department, School of Pharmacy, Muhimbili University College of Health and Allied Sciences, PO Box 65013, Dar Es Salaam, Tanzania

Tel: +255687884947

Citation: Sheila Maregesi M, Kauke B, Kagashe G, et al. Traditional Eye Medicines in Tanzania: Products, Health Risk Awareness and Safety Evaluation. Herb Med. 2016, 2:1.

Received: December 30, 2015; Accepted: January 27, 2016; Published: Janaury 29, 2016

\section{Introduction}

Traditional eye medicines (TEM) are commonly used in different countries. Products used vary from healer to healer and from country to country. Eye problems are many and may be categorized as; (i) Eye infections when pathogenic microorganisms invade any part of the eyeball or surrounding area. The infection may cause redness, pain, discharge, watering and light sensitivity (ii) Eye conditions e.g., cataract, dry eyes and eye allergies and, (iii) Vision impairment e.g., glaucoma, double vision (Diplopia) [1,2].

In Tanzania, like other developing countries the demand for eye care is growing. The dependency on TEM for care and treatment is attributed to several reasons including; few ophthalmologist, inability of medicines purchase and inadequate/distant health facilities to the majority [3]. The drawback of TEM is that, methods and products employed in treatment /management may lead to serious health problems including blindness.

Although TEMs is common in many countries, very few documentation focusing on plants/products used for traditional eye treatment do exist. Our literature search noted a systematic documentation from the study conducted in the Eastern Cape Province, South Africa where 12 plant species medicinal plants belonging to 9 families were documented [4]. Plants used for treatment of eyes diseases/conditions in Tanzania are documented in ethno pharmacological journal articles and books but in a scattered manner while the epidemiological data associated with TEM caused medical problems is scanty. 
The study was divided in parts namely; Part I dealt with the compilation of previous documented TEMs of Tanzania, Part II concerned with ethno pharmacological survey of TEM in Kigoma District, Part-III involved in assessment of knowledge and awareness of health risks associated with TEM and, Part IV covered safety evaluation based on determination of $\mathrm{pH}$ and microbial contamination.

\section{Methodology}

\section{Literature survey and data compilation}

Information on Tanzania medicinal plants for the treatment of eye diseases/conditions was compiled from journal articles and books. Main resources were the publications on the work done by Herdberg et al. [5-7], Chhabra et al. [8-13] and the books of Haerdi [14], Watt and Breyer-brandwijk [15], Kokwaro [16] and Ruffo et al. [17]. Other appropriate Tanzanian published articles are herein cited.

\section{Ethnophamarcological study}

Study site: Ethnomedical study was conducted in 9 wards (Bangwe, Buzebazeba, Gungu Kasingilima, Kitongoni, Mwanga Kusini, Mwanga Kasikazini, Machinjioni, Rusimbi) and 6 villages (Ilagala, Simbo, Luiche, Muyobozi, Mwandiga and Sunuka) of the Kigoma district, Tanzania.

Study design: The study followed five steps as outlined below.

Interview: Traditional healers and people who are knowledgeable about medicinal plants were interviewed to obtain traditional products used for treatment of eye problems. The interviews were conducted in their homes guided by the questionnaire (see the attached questionnaire in the annex). Both Kiswahili and vernacular languages were used to obtain reliable information.

Plant material collection, herbaria preparation and identification: In the field, information providers showed the mentioned plants to enable plant materials collection for safety evaluation and herbaria preparation. Identification of the prepared herbaria was done in Botany department, University of Dar Es Salaam.

\section{Awareness on health risks associated with TEM}

During the interview information providers tested on awareness of risks associated with the use of TEM based on three selected parameters namely; pain after administration, low vision and blindness.

\section{Safety evaluation}

$\mathrm{pH}$ determination and microbial detection were carried out in the Pharmacognosy Laboratory and Microbiology and virology Laboratory at the Muhimbili University of Health and Allied sciences using $\mathrm{pH}$ meter and following standard microbiology procedures.

pH determination: Preparation of each sample depending on product nature is outlined below. For each tested sample determination was carried out in triplicate, the mean of the obtained values was reported.
Extract preparation:1g of plant material from Vernonia amagdalina, Bidens pilosa, Ageratum conyzoides and Commiphora edulis were each macerated with $20 \mathrm{~mL}$ of distilled water for 12 hours, filtered to obtain the micelle.

Sap preparation: Leaves of Rumex usambarensis and Solanum lycopersicum were each pounded in the mortar and the sap/ juice squeezed and filtered.

Unrefined salt preparation: A solution of the salt was prepared by dissolving $0.9 \mathrm{~g}$ of salt in $100 \mathrm{~mL}$ of water.

Palm oil: $\mathrm{pH}$ determined using the oil without any dilution.

Determination of microbial contamination: Dry lizard droppings sample was collected from one of the MUHAS offices. The sample was enriched in Brain Heart Infusion Broth, incubated at $37^{\circ} \mathrm{C}$ for 18 hours. It was then direct cultured on solid media namely; Blood Agar (BA), Chocolate Agar (CA), MacConkey Agar (MCA) and Sabourad Dextrose Agar (SDA) followed by incubation of 48 hours and 72 hours respectively. This was followed on subculturing on similar media and preliminary identification of the microorganisms.

\section{Results}

\section{TEM data compiled from previous studies}

Data retrieved from journal articles and books gave 65 plant species belonging to 36 families summarized in Table 1. According to this data, proportions of the various plant parts used are presented in Figure $\mathbf{1}$ and the frequency of mention for the diseases/conditions is presented in Figure 2.

\section{Ethnopharmacological study in the Manyema Tribe}

Recorded TEM: This study was conducted in areas not covered in previous ethnopharmacological surveys done over two decades ago. Recorded products and their corresponding eye disease/ conditions are summarized in Tables 2 and 3.

Sources and dosage forms of TEM used by the Manyema tribe: Our study afforded to record 19 TEMs where fifteen are of plant origin belonging to 11 families (Table 2 ) with the frequency of mention for each plant shown in Figure 3.

Disease/conditions treated by TEM among the Manyema tribe: Six categories eye diseases/condition treated are as shown in Figure 4.

\section{Awareness of health risks associated with TEM}

Responses from information providers on the four negative health risks of TEM asked are presented in Table 4.

\section{Safety evaluation}

Based on the importance of $\mathrm{pH}$ and freeness from microbes in eye medicines, some products were evaluated. $\mathrm{pH}$ of tested products were acidic in nature as shown in Table 5 Microbial contamination was observed in the lizard droppings, as presented in Figure $\mathbf{3}$ and the preliminary identification of microorganisms in Table 6 . 
Table 1 Previous Reported Tanzanian plants used for treatment of eye disease/conditions.

\begin{tabular}{|c|c|c|c|c|}
\hline Family & Plant Name & Plant Part Used Preparation & Application & References \\
\hline Acanthaceae & Thunbergia alata Boj. Ex Sims & Whole plant used & Conjunctivitis & [14] \\
\hline \multirow[t]{2}{*}{ Amaranthaceae } & Aerva lanata (L) Juss. Ex schutt & Leave crushed and the juice used & Sore eyes & {$[16,17]$} \\
\hline & Achyranthes asperta $\mathrm{L}$ & Entire plant/aerial parts juice & $\begin{array}{l}\text { Used to dissipate opacity of } \\
\text { the cornea }\end{array}$ & [15] \\
\hline Asparagaceae & Asparagus africanus Lam. & Seeds swallowed & eye disease & [17] \\
\hline Anacardiaceae & Ozoroa insignis Del & Stem bark & Pink eyes & [15] \\
\hline Annonaceae & Annona senegalensis Pers & $\begin{array}{l}\text { Roots } \\
\text { Leaves }\end{array}$ & Eye lotion & [15] \\
\hline Apocynaceae & $\begin{array}{l}\text { Diplorhynchus condylocarpon } \\
\text { Mull. Arg }\end{array}$ & Roots & Sore eyes & [16] \\
\hline $\begin{array}{l}\text { Arecaceae } \\
\text { (Palmae) }\end{array}$ & Phoenix reclinata Jacq. & Leaves & Conjunctivitis & [16] \\
\hline Asparagaceae & Asparagus africanus Lam & The leaves infusion for washing the eyes. & Blindness & [8] \\
\hline \multirow[t]{5}{*}{$\begin{array}{l}\text { Asteraceae } \\
\text { (Compositae) }\end{array}$} & $\begin{array}{c}\text { Aspilnia mosambicensis (Oliv) } \\
\text { Wild }\end{array}$ & $\begin{array}{l}\text { Roots decoction vapor directed into eye and } \\
\text { Leaves juice as eye drops. }\end{array}$ & Conjunctivitis & [9] \\
\hline & $\begin{array}{l}\text { Blepharispermum } \\
\text { zanguebaricum Oliv and Hiern }\end{array}$ & The leaves pounded with water and the juice used. & Eye trouble & [9] \\
\hline & Conyza pyrrhoppa A. Rich & Leaves maceration & $\begin{array}{l}\text { Ophthalmic application in } \\
\text { cattle }\end{array}$ & [15] \\
\hline & Emilia coccinea (Sims) G. Don & $\begin{array}{c}\text { Infusion of the leaves mixed with those of Ipomea } \\
\text { eriocarpa used as eye drops }\end{array}$ & Eye disease & [17] \\
\hline & Microglossa pyrifolia Lam. & Juice of roots as eye drops & Cataract & [5] \\
\hline Bignoniaceae & $\begin{array}{l}\text { Mackhamia obtusifolia (Barker) } \\
\text { Spragae }\end{array}$ & Decoction of roots drunk & $\begin{array}{l}\text { Improve eye sight and } \\
\text { conjunctivitis }\end{array}$ & [10] \\
\hline \multirow[t]{2}{*}{ Boraginaceae } & Cordial ovalis $\mathrm{R} . \mathrm{Br}$ & Leaves & Eye ache & [5] \\
\hline & Cordia monoica (Roxb) & Leaves & Eye disease & [17] \\
\hline Bombacaceae & Adansonia digitata $\mathrm{L}$. & Leaves infusion used as eye drops & Eye disease & [17] \\
\hline \multirow[t]{3}{*}{ Caesalpiniaceae } & Afzelia quanzensis Welw & $\begin{array}{l}\text { Pounded leaves, filtered and the juice used as eye } \\
\text { drops }\end{array}$ & Conjunctivitis & [8] \\
\hline & Brachystegia spiciformis Benth & $\begin{array}{l}\text { Decoction of roots together with an infusion of } \\
\text { leaves }\end{array}$ & Conjunctivitis & [15] \\
\hline & Cassia auriculata (L) & Powdered dry stem bark mixed with water drunk. & Conjunctivitis & [8] \\
\hline Capparidaceae & Capparis tomentosa Lam & Roots decoction is drunk & $\begin{array}{l}\text { Eye problems } \\
\text { Conjuctivitis }\end{array}$ & [16] \\
\hline Commelinaceae & Commelina benghalensis (L) & $\begin{array}{l}\text { Sap used as eye drops Roots decoction is warmed } \\
\text { with camphor used as eye drop. }\end{array}$ & Eye ailments Conjunctivitis & {$[9,17]$} \\
\hline Convolvulaceae & Ipomea eriocarpa $\mathrm{R}$. Br. & $\begin{array}{l}\text { Infusion of the leaves mixed with those of Emilia } \\
\text { cocciea used as eye drops }\end{array}$ & Eye disease & [17] \\
\hline \multirow[t]{8}{*}{ Euphorbiaeae } & Acalypha fructosa Forssk & $\begin{array}{c}\text { Aerial part decoction } \\
\text { Leaves used decoction } \\
\text { Root decoction } \\
\text { Either of the above applied into the eye. }\end{array}$ & Conjunctivitis & [15-17] \\
\hline & Bridelia micarantha Hochst & Leaf sap & Sore eyes & [17] \\
\hline & Euphorbia hirta (L) & $\begin{array}{l}\text { Whole plant infusion used as eye drop } \\
\text { Leaves }\end{array}$ & $\begin{array}{l}\text { Conjunctivitis } \\
\text { Eyes trouble }\end{array}$ & $\begin{array}{l}{[14]} \\
{[16]}\end{array}$ \\
\hline & Euphorbia candelabrum Tremaux & The latex & Eye tumor & [15] \\
\hline & Euphorbia tirucalli L. & Latex is applied into the eye. & Eyes infection & [18] \\
\hline & $\begin{array}{l}\text { Felicia grantii (Oliv. \& Hiern) } \\
\text { Grau, }\end{array}$ & Plant sap is used as eye drops & Eye infection & [18] \\
\hline & $\begin{array}{l}\text { Pseudolachnostylis } \\
\text { maprouneifolia Pax }\end{array}$ & Leaves & Eyes trouble & [14] \\
\hline & Spirostachys africana Sond & $\begin{array}{l}\text { Leaves pounded then boiled with water and the } \\
\text { vapor let into eyes }\end{array}$ & Eye trouble & [10] \\
\hline Fabaceae & Crotalaria retusa $\mathrm{L}$. & Leaf juice used as eye drops & Eye infection & [18] \\
\hline
\end{tabular}




\begin{tabular}{|c|c|c|c|c|}
\hline Hydnoraceae & Vismia orientalis Engl & $\begin{array}{l}\text { The leaves burned and the ashes mixed with water } \\
\text { and used as eye drop. }\end{array}$ & Sore eyes & [10] \\
\hline \multirow[t]{2}{*}{ Labiatae } & Leonotis mollissima (Gurke) & Young leaves and buds juice applied to the eyes & Conjunctivitis & [6] \\
\hline & Ocimum suave Wild & Leaves & $\begin{array}{l}\text { Sore eyes } \\
\text { Conjunctivitis }\end{array}$ & [16] \\
\hline \multirow[t]{2}{*}{ Loganiaceae } & Strychnos madagascanensis Poir. & Infusion of the leaves is used to wash the eyes. & Conjunctivitis & [11] \\
\hline & Strychnos spinosa Lam. & Leaves & Conjunctivitis & [15] \\
\hline Mimosaceae & $\begin{array}{l}\text { Albizia verscolor } \\
\text { Welw Ex oliv }\end{array}$ & Stem bark & Irritating eyes & [14] \\
\hline \multirow[t]{2}{*}{ Moraceae } & Ficus capensis Thumb & $\begin{array}{l}\text { The leaves are pounded, mixed water then filtered } \\
\text { and the juice used to wash eyes. }\end{array}$ & $\begin{array}{l}\text { Septic eye } \\
\text { Conjuctivitis }\end{array}$ & [15] \\
\hline & Ficus exasperate Vahl & Leaves & Eyes trouble & [15] \\
\hline Ochnaceae & Brackenridgea zanguebarica Oliv & $\begin{array}{l}\text { Stem bark is boiled with water and the vapor let } \\
\text { into eye. }\end{array}$ & Conjunctivitis & [11] \\
\hline Olacaceae & Ximenia caffra Sond & Leaf juice mixed with little water. & $\begin{array}{l}\text { Itchy eye in the treatment } \\
\text { of trachoma, especially in } \\
\text { children. }\end{array}$ & {$[6]$} \\
\hline \multirow[t]{5}{*}{ Papilionaceae } & Abrus precatorius (L) & $\begin{array}{l}\text { Leaves juice/decoction } \\
\text { Seeds infusion }\end{array}$ & $\begin{array}{c}\text { Conjunctivitis/ } \\
\text { inflamed eyes } \\
\text { Purulent eye infections }\end{array}$ & {$[7,14]$} \\
\hline & Cajanus cajan (L) Mill sp & Leaves juice & Bad vision & [7] \\
\hline & Crotalaria emargiata Benth & Leaves juices & $\begin{array}{l}\text { Eye disease } \\
\text { Eye sores }\end{array}$ & [16] \\
\hline & Dolichos trilobus L & Leaf juice is boiled, cooled and applied. & Cataract. & [7] \\
\hline & $\begin{array}{l}\text { Desmodium salicifolium } \\
\text { (Poir) DC }\end{array}$ & Leaves & Eye trouble & [16] \\
\hline \multirow[t]{3}{*}{ Polygonaceae } & Carpolobia goetzei Gurke & $\begin{array}{l}\text { Roots infusion with the decoction of Vigna } \\
\text { unguiculata taken orally in the porridge. }\end{array}$ & Conjuctivitis & [16] \\
\hline & $\begin{array}{l}\text { Oxygonum sinuatum (Hochst. \& } \\
\text { Steud ex Meisn.) Dammer }\end{array}$ & Leaves squeezed and juice used as eye drops & Conjuctivitis & [17] \\
\hline & $\begin{array}{l}\text { Securidaca longependunculata } \\
\text { Fresen. }\end{array}$ & Roots barks cold infusion & Used as eye remedy & [7] \\
\hline \multirow[t]{3}{*}{ Rubiaceae } & $\begin{array}{l}\text { Agathesanthemum bojeri } \\
\text { Klotzsch }\end{array}$ & The leaves juice is used as eye drop. & Eye pain. & [12] \\
\hline & $\begin{array}{l}\text { Crossopteryx febrifuga (G. Don) } \\
\text { Benth. }\end{array}$ & $\begin{array}{l}\text { Leaves } \\
\text { as an ingredient in ointment }\end{array}$ & $\begin{array}{c}\text { Conjunctivitis. } \\
\text { Filaria of connective tissues } \\
\text { in the eye }\end{array}$ & {$[7,16,19]$} \\
\hline & Polysphaeria parvifolia Hiern & The roots are infusion taken orally. & Blindness & [12] \\
\hline Rutaceae & Vepris glomerata (F. Hoffm) Engl & $\begin{array}{l}\text { The powdered dried root bark is added to boiling } \\
\text { water and the eye exposed to the vapors }\end{array}$ & Eye trouble & [12] \\
\hline Sapindaceae & $\begin{array}{l}\text { Allophylus rubifolius (Rochst. Ex } \\
\text { a. Rich) Engl. }\end{array}$ & The root decoction is drunk. & Conjunctivitis & [12] \\
\hline \multirow[t]{2}{*}{ Sapotaceae } & Sideroxylon inerme $\mathrm{L}$ & The dried powdered root in porridge and eaten. & Conjunctivitis & [13] \\
\hline & Paullinia pinnata L. & Leaves & $\begin{array}{l}\text { Blindness and other eyes } \\
\text { troubles. }\end{array}$ & [16] \\
\hline Smilacaceae & Smilax kraussiana Meisn & Leaves & Eye troubles & [16] \\
\hline Solanaceae & Solanum incanum $\mathrm{L}$ & Extract juice of leaves & Eye diseases & [7] \\
\hline Sterculiaceae & Waltheria indica $\mathrm{L}$ & $\begin{array}{l}\text { Roots used as an } \\
\text { astringent } \\
\text { Leaves juice }\end{array}$ & Eye ache & [16] \\
\hline \multirow[t]{4}{*}{ Tiliaceae } & Grewia plagiophylla K. Schum & Fibres infusion used to wash the eyes. & $\begin{array}{l}\text { Eye irritation due to any } \\
\text { irritating substances like } \\
\text { pepper }\end{array}$ & [16] \\
\hline & Carpodiptera africana Mast. & $\begin{array}{c}\text { The roots or stem bark infusion the face and eyes } \\
\text { washing }\end{array}$ & Eyes trouble & [13] \\
\hline & Grewia villosa Wild & Leaves decoction & Eye pain & [16] \\
\hline & Triumfetta rhomboidea Jacq. & Roots infusion or decoction is drunk & Eyes trouble & [15] \\
\hline Verbenaceae & Lantana camara $\mathrm{L}$ & Leaf ashes & Conjunctivitis & {$[16,17]$} \\
\hline
\end{tabular}


Table $\mathbf{2}$ Recorded herbal traditional eye medicines used by the Manyema tribe.

\begin{tabular}{|c|c|c|c|c|}
\hline Family & $\begin{array}{l}\text { Plant name and frequency } \\
\text { of mention }\end{array}$ & $\begin{array}{l}\text { Vernacular } \\
\text { name } \\
\text { (Manyema) }\end{array}$ & Plant part, Preparation and Administration & $\begin{array}{l}\text { Eye disease or } \\
\text { condition }\end{array}$ \\
\hline \multirow{3}{*}{$\begin{array}{l}\text { Asteraceae } \\
\text { (Compositae) }\end{array}$} & Bidens pilosa $\mathrm{L}$. & Kasisa & $\begin{array}{l}\text { Fresh leaves are squeezed and juice used as eyes drop, } 3 \\
\text { drops, three times a day for seven days }\end{array}$ & $\begin{array}{l}\text { Cataract and eye } \\
\text { infections }\end{array}$ \\
\hline & Ageratum conyzoides $L$. & Mkokoa & $\begin{array}{c}\text { Fresh leaves are squeezed and juice used as eyes drops, } \\
\text { three times a day for seven days. }\end{array}$ & $\begin{array}{l}\text { Vision disability } \\
\text { Eye infections }\end{array}$ \\
\hline & Vernonia amygdalina Del. & Kilulugunja & $\begin{array}{l}\text { Fresh leaves are squeezed and juice used as eyes drops, 2-3 } \\
\text { drops used three times a day for seven days. }\end{array}$ & Cataract \\
\hline Arecaceae & Elaesis guineensis Jacq & Mawese & Palm oil is used as eye drops. Once a day preferably at night. & Vision improvement \\
\hline Burseraceae & $\begin{array}{l}\text { Commiphora edulis } \\
\text { (Klotzsch) Engl. }\end{array}$ & Msubesube & $\begin{array}{l}\text { Fresh latex produced after leaves detaches from the stem } \\
\text { three applied daily until recovery. }\end{array}$ & Cataract \\
\hline Crassulaceae & $\begin{array}{l}\text { Kalanchoe lanceolata } \\
\text { (Forssk.) }\end{array}$ & $\begin{array}{l}\text { Mchawi } \\
\text { hanaakili }\end{array}$ & $\begin{array}{l}\text { Fresh leaves are warmed and the squeezed juice used as eye } \\
\text { drops. 2-3 drops two times a day }\end{array}$ & Sore eyes and itching. \\
\hline \multirow[b]{2}{*}{ Euphobiaceae } & $\begin{array}{l}\text { Phyllanthus amarus Schum. } \\
\text { \& Thonn. }\end{array}$ & Mnyumanyuma & $\begin{array}{c}\text { Fresh leaves are squeezed and juice used as eyes drops, 2-3 } \\
\text { drops used three times a day for seven days. }\end{array}$ & Cataract \\
\hline & Euphorbia hirta L. & Songosongo & $\begin{array}{l}\text { Fresh latex from dettached leaves, three drops used for } \\
\text { three times a day }\end{array}$ & Cataract \\
\hline Moraceae & Ficus natalensis Hochst & Murumba & $\begin{array}{l}\text { Fresh latex produced from bark, } 2-3 \text { drops is used three } \\
\text { times a day }\end{array}$ & Eye tumour \\
\hline Meliaceae & Swietenia macrophylla King & Mninga & Fresh latex produced from bark, one drop is used once a day & Cataract \\
\hline Papilionaceae & Abrus prectorius $\mathrm{L}$. & Sikesike & $\begin{array}{c}\text { Fresh leaves are squeezed and juice used as eyes drops. } 3 \\
\text { drops three times a day for seven days. }\end{array}$ & Cataract \\
\hline Pedariaceae & $\begin{array}{l}\text { Sesamum angustifolium } \\
\text { (Oliv.) Engl }\end{array}$ & Mulenda & Fresh leaves are squeezed and juice used as eyes drops. & $\begin{array}{l}\text { Eye infection (newly } \\
\text { born babies' eyes are } \\
\text { affected with measles). }\end{array}$ \\
\hline Polygonaceae & $\begin{array}{l}\text { Rumex usambarensis } \\
\text { (Dammer) Dammer }\end{array}$ & Lusaba & $\begin{array}{l}\text { Aerial parts are squeezed and the juice used as eye drops } \\
\text { two times daily until recovery. }\end{array}$ & Cataract \\
\hline \multirow{2}{*}{ Solanaceae } & Solanum lycopersicum L. & Nyanya & Fresh leaves are squeezed and juice used as eyes drops. & $\begin{array}{l}\text { Cataract, } \\
\text { vision problems }\end{array}$ \\
\hline & Solanum tuberosum L. & $\begin{array}{l}\text { Viazi mviringo } \\
\text { Viazi mbatata }\end{array}$ & $\begin{array}{c}\text { Raw of potato tuber are crushed in a mortar and strained to } \\
\text { obtain the juice is applied as eye drops. }\end{array}$ & $\begin{array}{l}\text { Improves the poor } \\
\text { vision }\end{array}$ \\
\hline
\end{tabular}

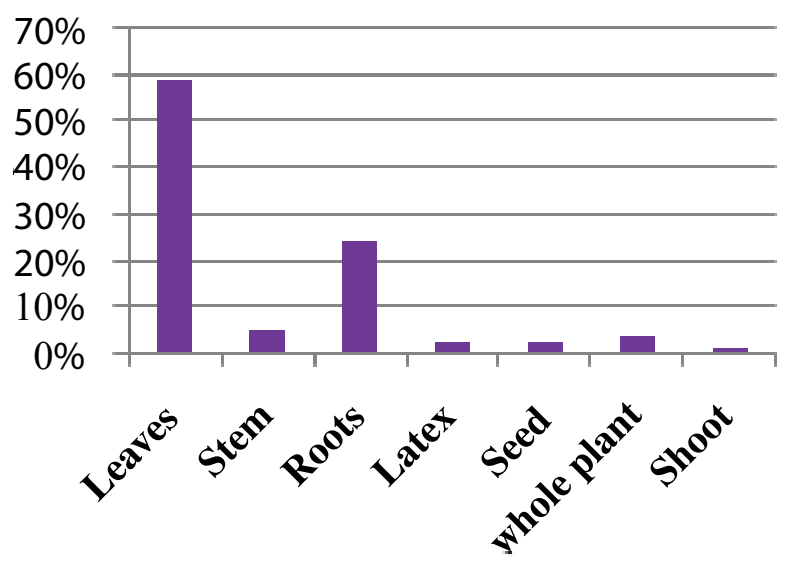

Figure 1 Proportion of plant parts.

\section{Discussion}

In previous studies, the use of ambiguous terminologies such as; eye problems, eye diseases, eye trouble, eye ailments, eye

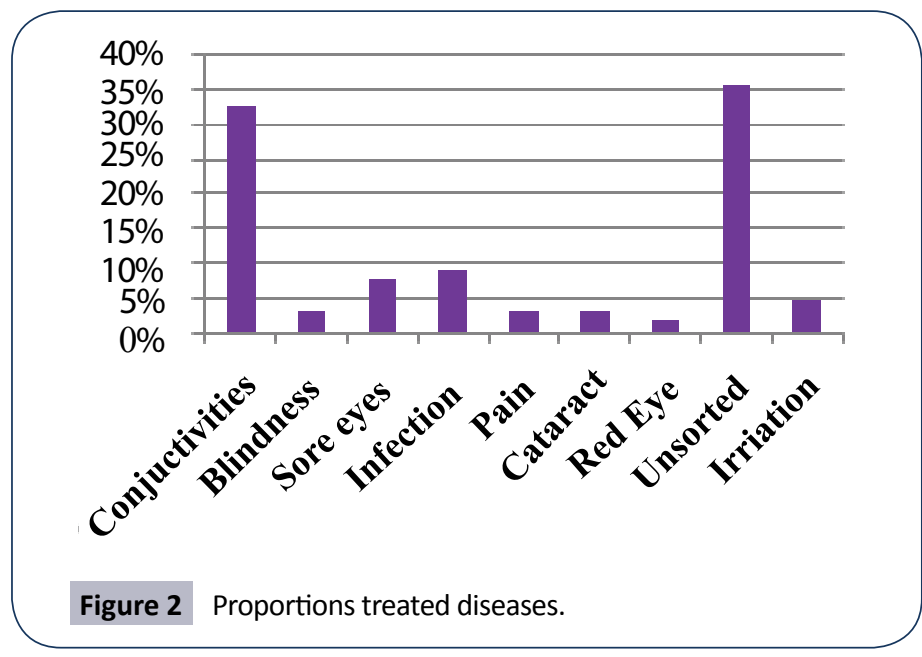

ache/pain could not clearly state the disease /condition. This is a drawback if one would wish to conduct scientific research for drug development. Leaves were ranking highest followed by roots. By disregarding the unsorted disease/condition (37\%); eye 
conjunctivitis (33\%) was the most treated disease followed by eye infection (12\%) (Figures 4).

Among the recorded TEM in the Manyema tribe, five plants namely; Abrus precatorius, Ageratum conyzoides, Bidens pilosa, Euphorbia hirta and Sesomum angustifolia had previously been reported. Majority of the products (78.9\%) were herbal preparation, $15.8 \%$ were animal wastes and the unrefined salt as the only mineral product. This is in line with the fact that, botanicals are the main source of traditional medicine. The most used photo-organs are leaves constituting 60\%. Product-wise; palm oil was the most frequently mentioned followed by latex of Euphorbia hirta and a solution of unrefined salt. Dosage forms comprised of liquid (juices/saps; $52.6 \%$, latex; $21.1 \%$ ), and oil; $5.2 \%)$ and solid (21.1\%) as powders from animal source.

Unlike the data obtained from previous studies, information providers clearly stated the eye disease/condition yielding quality/reliable data for further scientific studies. In part this is due the well-structured questionnaire that gave proper guidance during the interview. Cataract was the most reported among mentioned six eye disease/problem. In part, this could be due to inadequate hospital services or dislike of undergoing surgical operation. It is worth investigating cataract treating TEM as efficacy can easily be assessed by disappearance of the cataract. Another area of interest for future research is on TEM used for vision improvement in order to confirm efficacy and establish safety and mechanism of action(s).

It should be clear that, we are not advocating the use TEM products reported in this work. However, ethno medical data and little scientific data from literature provide association and conviction on the use of the mentioned plants as TEM as presented below;

Bidens pilosa is used to treat cattle eye keratitis [20]. In vitro studies on extracts of $B$. pilosa have demonstrated antimicrobial activity against a wide range of bacteria including Klebiseilla pneumonia, Bacillus, Neisseria gonorrhea, Pseudomonas, and Salmonella, Mycobacterium tuberculosis and $M$. smegmatis [21]. Aqueous leaf extract showed significant anti-yeast activity towards Candida albicans. Polyacetylenes are linked with most of the observed antimicrobial activity and particularly phenylheptatriyne that had shown strong in vitro activity against numerous human and animal viruses, bacteria, fungi and molds in low concentrations $[22,23]$. Some of these pathogenic microbes are responsible for causing eye infection justifying the antimicrobial use this plant.

Ageratum conyzoides in combination with Dichrocephala integrifolia leaf sap is applied as eye drops in Tanzania and other African countries [24]. It is also used for treatment of blindness, conjunctivitis and related ocular infections in cattle [25].. Among several antimicrobial testing studies, water and ethanolic extracts had exhibited activity against methicillin-resistant Staphylococcus aureus (MRSA). Phytochemical constituents of $A$. conzyoide include alkaloids, coumarins, essential oils, tannins various flavonoids including polymethoxylated flavones and polyhydroxyflavones [26]. The plant has limited medicinal applications due toxicity [27].
The use of leaf juice/decoction of Abrus prectorius is reported for treatment of conjunctivitis and inflamed eyes and seeds infusion against purulent eye infections $[7,15]$. In cases of cataracts, refractive errors while ocular pain, some healers ask patients to take the seeds of Abrus precatorius orally, and apply root sap into the conjunctival sac [28]. In Africa, powdered seed is added to women's traditional eye makeup in African countries [29]. The methanolic seed extracts showed comparable antibacterial activity to Streptomycin when tested against Enterococcus faecalis, Escherichia coli, Micrococus luteus, Lactobacillus fermentum, Klebsilla pneumonia, Staphylococcus aureus, Streptococcus thermophilus, Streptococcus mitis and Streptococcus mutans [30].

In India, the stem latex of Euphorbia hirta is used for the treatment of eyelid styes and eye sores. Flower decoction is used against eye infections and inflammations such as conjunctivitis or pink eye [31].. Various parts of E. hirta had shown various degrees of antibacterial and antifungal activity against Staphylococcus aureus, Micrococcus sp., Bacillus subtilis, Bacillus thuringensis, Escherichia coli, Klebsiella pneumonia, Salmonella typhi, Proteus mirabilis and the yeast Candida albicans [32]. Interesting antiviral activity had been reported and associated with tannins for the high antiretroviral activity [33]

Leaf juice of Kalanchoe lanceolata is reported to treat sore and itching eyes and other Kalanchoe species are used to treat ailments such as infections, rheumatism and inflammation [34]. Ficus natalensis leaf latex is used to treat cataract [35] and for cattle treatment with regard to blindness, conjunctivitis and related ocular infections [25]. Similarly, latex of the related species Ficus thorningii is used as eye drops for eye wound treatment [19].

Palm oil obtained from Elaesis guineensis is rich in natural carotenes as well as tocopherols and tocotrienols that are normally converted into vitamin A in the body when taken orally [36]. The oil is known for faster healing of bruises, sunburn and cuts [37]. In connection to the popular use of palm oil as eye drops to improve vision among the Manyema tribe, studies to confirm its efficacy and mechanism of action(s) is worth undertaking.. Swietenia macrophylla is an endangered species but widely used in folk medicine to treat various diseases. It has shown several pharmacological activities inter alia, antimicrobial, anti-inflammatory, antiviral, anticancer and antitumor activities [38].

This work reports the use of Solanum lycopersicum leaf juice for treatment of cataract and visual improvement. In Australia it used for unspecified eye problems [39]. Leaf decoction taken orally is useful in optic nerve and eye weakness [40]. The observed leaf juice $\mathrm{pH}$ was 5.3 is too acidic for the application into the eyes. Unpublished data from Mbeya region, Tanzania associate application of leaf juice with blindness in that locality. From the same genus, we report about Solanum tuberosum sap for improvement of the poor vision. This may be linked with the previous report on the potato pulp claimed to reduce the inflammation of the veins that arise under the eyes [41] and is in agreement with the anti-inflammatory effects of potato glycoalkaloids [42]. Despite the mentioned benefits, lack of sterility, is likely to be the source of microbial introduction leading to eye infection. 
Table 3 Recorded non herbal Traditional Eye Medicines used by the Manyema tribe.

\begin{tabular}{|c|c|c|c|c|}
\hline Product & Scientific name & Swahili name & Preparation and Administration & Eye disease or condition \\
\hline Crude salt & $\begin{array}{l}\text { Sodium Chloride } \\
\text { (Unrefined) }\end{array}$ & Chumvi ya mawe & $\begin{array}{l}\text { 1-2 teaspoons is raw salt is dissolved in } 250 \mathrm{ml} \text {. of } \\
\text { clean water. }\end{array}$ & Red eyes \\
\hline Lizard droppings & - & Mavi ya mujusi & $\begin{array}{l}\text { Powdered lizard's excreta is applied directly to the } \\
\text { eyes. The treated eyes should remain closed for a } \\
\text { minimum of one hour. The treatment is repeated once } \\
\text { daily until the cataract disappears. }\end{array}$ & Cataract \\
\hline Snail shells & Molluscs & Gamba la konokono & The shell's powder is used for treatment of cataract & Cataract \\
\hline Python's excreta & - & Mavi ya chatu & $\begin{array}{l}\text { Powdered python's excreta is applied directly to } \\
\text { the eye. The treated eye should remain closed for a } \\
\text { minimum of one hour. The treatment is repeated once } \\
\text { daily until the cataract disappears. }\end{array}$ & Cataract. \\
\hline
\end{tabular}

Table 4 Awareness on Risks of Traditional Eye Medicine.

\begin{tabular}{|c|c|c|}
\hline Risks/Consequences & Response & Percentage \\
\hline Pain after administration & 2 & $10 \%$ \\
\hline Low vision & 1 & $5 \%$ \\
\hline Blindness & 4 & $20 \%$ \\
\hline Not aware & 13 & $65 \%$ \\
\hline
\end{tabular}

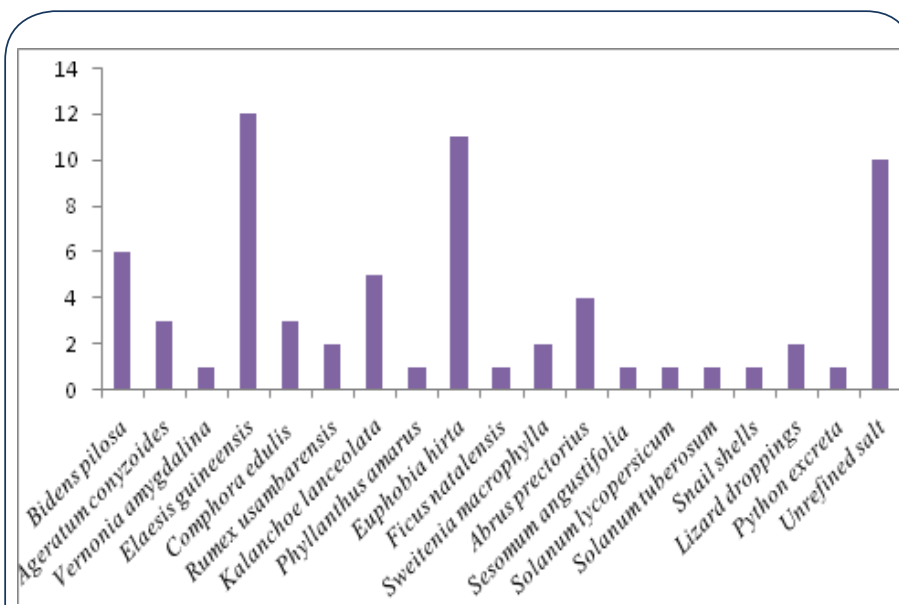

Figure 3 Frequency of mentioned among recorded plants.

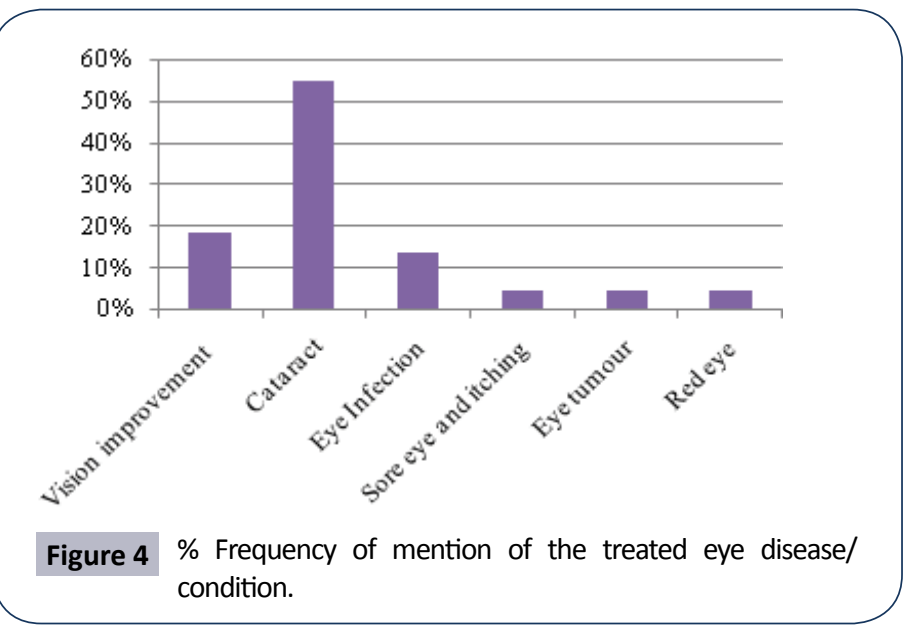

In the Indian Ayurvedic system of medicine Phyllanthus amarus is used for treatment of various diseases including ophthalmopathy. The extracts and compounds isolated from $P$. amarus showed a

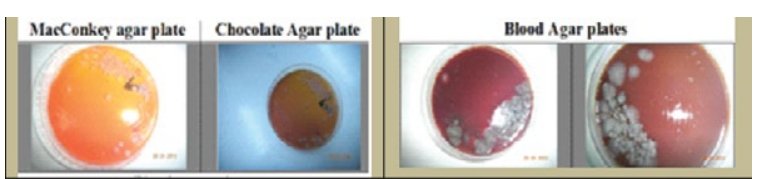

Figure 5 Plates showing microbial growth.

Table $5 \mathrm{pH}$ of Traditional Eye Medicine Products.

\begin{tabular}{|c|c|c|}
\hline Plant/Product & Extraction & $\mathbf{p H}$ \\
\hline Vernonia amagdalina & Extract & 5.61 \\
\hline Bidens pilosa & Extract & 5.21 \\
\hline Ageratum conyzoides & Extract (1:40 dilution) & 5.7 \\
\hline Commiphora edulis & Extract & 5.3 \\
\hline Rumex usambarensis & Extract & 5.6 \\
\hline Solanum lycopersicum & Sap & 2.5 \\
\hline Palm oil (local market & Sap & 5.7 \\
\hline quality) & Unaltered & 4.91 \\
\hline Palm oil and isotonic & $1: 1$ (V:V) & 4.54 \\
\hline solution & $1: 100$ & 4.78 \\
\hline Palm oil and Water & Pure & 6.81 \\
\hline Distilled water & $0.9 \mathrm{~g}$ in 100mls water & 6.6 \\
\hline Unrefined salt & $0.9 \mathrm{~g}$ in 100mls water & 6.57 \\
\hline Isotonic solution & & \\
\hline
\end{tabular}

Table 6 Preliminary identification Microbes in the lizard droppings.

$\begin{array}{cl}\text { Bacteria } & \text { Gram positive bacteria: Streptococcus species, Bacillus } \\ & \text { species Staphylococcus aureus } \\ & \text { Gram negative bacteria: E. coli } \\ \text { Fungi } & \text { Yeast and molds: Candida albicans, Aspergillus species }\end{array}$

wide spectrum of pharmacological activities including antiviral, antibacterial, anti-inflammatory, antimicrobial etc. [43]. The leaf juice of another reported plant Sesamum angustifolia is used as eye drops and lubricant in Zimbabwe [44]. Supporting our report on Rumex usambarensis, the plant is also used as eye drops in other countries of Africa [45]. In addition to humans application, the fresh leaf juice is used for cattle eye diseases including eye filariosis and malignant tumour [20]. Related species had shown antimicrobial activities e.g., Rumex nepalensis that showed significant antibacterial activity [46] and Rumex cyprius fruits reported to have antiviral activity [47]. Finally, is the plant Vernonia 
amygdalina whose leaf extract showed antibacterial activity against Staphyloccocus aureus, Bacillus cereus, Escherichia coli, Salmonela typhi, and Shigella dysenteriae $[48,49]$ though not related with cataract treatment as reported herein.

The use of salt solution as TEM is in agreement with the traditional practice where unrefined salt solution is used for washing the eyes and regarded harmless [50] or flushing of eyes with salt solution for treating conjunctivitis caused by viruses or allergies since antibiotics are not useful in such cases [51]. Furthermore, the study conducted in Tanzania among patients at the ophthalmology clinics in Dar es Salaam reported $16 \%$ of those using TEM applied salt solution [52].

In Tanzania the epidemiological data pertaining to the drawbacks of using TEMs is scanty. A study conducted in Tanzania by Foster and Johnson [53] showed $25 \%$ of corneal ulcers associated with the use of traditional eye medicines indicating the magnitude of the problem. In our study $\mathrm{pH}$ and microbial contamination were used to assess safety since ophthalmic products are supposed to be isotonic and sterile. Ophthalmic solutions are recommended to have the same $\mathrm{pH}$ as the lacrimal fluid i.e. 7.4 although $\mathrm{pH}$ values ranging 7 to 9 are tolerated by the eye without marked irritation [54]. The pH obtained was ranging from 2.5 to 6.57 . Acidic products are not safe to the eyes as they are known to cause considerable redness and burning effects [55].

Python excreta, Lizard droppings are harmful TEM and sources of microbial contamination likely to cause infection. It is unfortunate similar products are also used as TEM in other countries, they include; a ground cowries, donkey and cow dung, human sputum, bird urine, etc. [50]. Culturing of the lizard droppings revealed contamination with Gram positive and Gram negative bacteria as well as yeast and molds. Applying this product introduces pathogenic microbes that may cause suppurative keratitis, followed by endophthalmitis and panophthalmitis leading to blindness. Keeping in mind that, TEM are commonly used in poor countries with the majority of the patients with AIDS, microbial contaminated TEM products subject them to contract many different fungal infections of the eye [2]. Noted during the interview was lack of sterility in TEM products during preparation and packing. In case of prolonged use, the product is kept for some days until mold growth is visible with naked eyes. This is another way of contaminating TEM with pathogenic microorganisms.

Due to unawareness on the negative health risks associated with TEM traditional healers prefer using substances that cause pain and irritation. The effects are considered as temporary and painful medications in particular as therapeutically effective. TEMs causing pain are likely to bring great damage to both extraocular tissues and/or intraocular tissues of perforated eyes [3]. The reported case from Nigeria where a 39 old man suffered from ocular discomfort and eventually blindness after applying the raw cassava extract in eyes [56] is a good example to disqualify such thinking.

\section{Conclusion}

Majority of TEMs reported in this study are from botanical sources. Waste products from animals normally contaminated with pathogenic microbes are also used. $65 \%$ among the information providers were unaware of the risks associated with TEMs use. Pain experienced does not worry majority of the information providers although ignoring such complains subject users to health risks of eye damage. Sterility which is a vital aspect for ophthalmic products is lacking, traditional healers need to be informed on the importance of this aspect. All samples whose $\mathrm{pH}$ was determined were acidic in nature; a state that is not safe for the eyes. Since TEM is a common practice in Tanzania and other developing countries, there is a need to educate the public on this situation so as to rescue the users from blindness. On the other hand, scientific studies are essential to identify bioactive compounds and develop safe products. 


\section{ANNEX: OUESTIONNARE FOR ETHNOMEDICAL STUDY ON TRADITIONAL EYE DISEASES/CONDITIONS}

1. Source of information:

i) Name of traditional healer/ herbalist/ others

ii) Age and education level:

iii) Sex:

iv) Date:

v) Address:

vi) Level of education:

vii) Tribe:

2. Do you treat any eye diseases/condition? Yes/No.

3. If yes, what are they?

4. Which of the mentioned diseases/condition do you treat and have obtained positive results?

5. Which plant(s) and plant part(s) do you use?

6. Do you use a one or a mixture of plants in treating your patients?

7. Besides plant material(s) do you use other products like minerals or animal products? Yes/No.

8. If yes what are they? (Vernacular names):

9. Do you have any specific time/season for collection and storage conditions for you plant material?

10. How to you prepare your medicine? (e.g. soaking/boiling in water, powdering, juice, latex etc.)

11. How do you administer your medicine to your patients (e.g. orally, topical application, eye drop etc.):

12. What amount/quantity of medicine do you administer to your patient at one time?

13. How many times per day is the medicine to be taken?

14. With regard to the amount of medicine given, does the age/ weight matter? Yes/No

15. If yes, how do you determine the amount to be given to your patients:

16. How long does the patient have to take the medicine?

17. Are you aware of any side effect (madhara) such as blindness that can be caused for using your medicine?

18. Do make any follow - up of your patient to see if they fully recovered?

19. Are you willing to show me the plant(s) so that we can carry out some scientific research to confirm their efficacy. Yes/No

20. If №, what reasons do you have for that? If Yes, what are your future expectations from scientific findings: 


\section{References}

1 Haddrill M (2009) Eye Infections: Bacterial, Fungal and Viral. Available at: http://www.allaboutvision.com/conditions/eye-infections.htm

2 Klotz SA, Penn CC, Negvesky, GJ Butrus (2000). Fungal and Parasitic Infections of the Eye Fungal and Parasitic Infections of the Eye. Clin Microbiol Rev 13: 662-685.

3 Mselle J (1998) Visual impact of using traditional medicine on the injured eye in Africa. Acta Tropica 70: 185-192.

4 Pendota SC, Grierson DS, Afolayan AJ (2008) An ethnobotanical study of plants used for the treatment of eye infections in the Eastern Cape Province, South Africa. Pak J Biol Sci 11: 2051-2053.

5 Hedberg I, Hedberg O, Madati PJ, Mshigeni KE, Mshiu EN, et al. (1982) Inventory of plants used in traditional medicine in Tanzania. I. Plants of the families Acanthaceae to Cucurbitaceae. Journal of Eth pharma 6: 29-60

6 Hedberg I, Hedberg O, Madati PJ, Mshigeni KE, Mshiu EN, et al. (1983) Inventory of plants used in traditional medicine in Tanzania. II. Plants of the families Dilleniaceae to Opiliaceae. Journal of Ethnopharmacology 9: 105-128.

7 Hedberg I, Hedberg O, Madati PJ, Mshigeni KE, Mshiu EN, et al. (1983) Inventory of plants used in traditional medicine in Tanzania. III. Plants of the families Papilionaceae to Vitaceae. Journal of Ethnopharmacology 9: 237-260.

8 Chabbra SC, Mahunnah RLA, Mshiu EN (1987) Plants used in traditional medicine in Eastern Tanzania. I. Pteridophytes and Angiosperms (Acanthaceae to Canellaceae). Journal of Ethnopharmacology 21: 253-277.

9 ChabbraSC, Mahunnah RLA, Mshiu EN (1989) Plants used in traditiona medicine in Eastern Tanzania. II. Angiosperms (Capparidaceae to Ebenaceae). Journal of Ethnopharmacology 25: 339-359.

10 Chabbra SC, Mahunnah RLA, Mshiu EN (1990) Plants used in traditional medicine in Eastern Tanzania. III. Angiosperms (Euphorbiaceae to Menispermaceae). Journal of Ethnopharmacology 28: 255-283.

11 Chabbra SC, Mahunnah RLA, Mshiu EN (1990) Plants used in traditional medicine in Eastern Tanzania. IV. Angiosperms (Mimosaceae to Papilionaceae). Journal of Ethnopharmacology 29: 295-323.

12 Chabbra SC, Mahunnah RLA, Mshiu EN (1991) Plants used in traditional medicine in Eastern Tanzania. V. Angiosperms (Passifloraceae to Sapindaceae). Journal of Ethnopharmacology 33: 143-157.

13 Chabbra SC, Mahunnah RLA, Mshiu EN (1993) Plants used in traditional medicine in Eastern Tanzania. VI. Angiosperms (Sapotaceae to Zingiberaceae). Journal of Ethnopharmacology 39: 83-103.

14 Haerdi F (1964) Die Eingeborenen - heilpflanzen des Ulanga distriktes Tanganyika (Ostafrika). Acta Tropica Supplement 8: 1-278.

15 Watt JM, Breyer-Brandwijk MG (1962) Medicinal and poisonous plants of Southern and Eastern Africa. Livingstone. 2nd edn. E \& S Livingstone Ltd., Edinburgh, London.

16 Kokwaro JO (1976) Medicinal Plants of East Africa. East Africa literature Bureau, Nairobi.

17 Ruffo CK, Birnie A, Tengrias B (2002) Edible wild plants of Tanzania. RELMA technical handbook series 27. Nairobi, Kenya: Regional land management unit (RELMA), Sida.
18 Maregesi SM, Ngassapa OD, Pieters LC, Vlietinck AJ (2007) Ethnopharmacological survey of the Bunda district, Tanzania: Plants used to treat infectious diseases. Journal of Ethnopharmacology 113: 457-470.

19 Bouquet A (1969) Féticheurs et médecines traditionnelles du Congo (Brazzaville). Mém. ORSTOM 36: 282.

20 Bizimana N (1994) Traditional veterinary practice in Africa. Deutsche Gessllschaftfur. Technische zusammenarbeit (GTZ) GmbH.

21 Mvere B (2004) Bidens pilosa L. Record from Protabase. In: Grubben GJH \& Denton OA (Eds). PROTA (Plant Resources of Tropical Africa/ Ressources végétales de l'Afrique tropicale), Wageningen, The Netherlands.

22 Adedapo A, Jimoh F, Afolayan A (2011) Comparison of the nutritive value and biological activities of the acetone, methanol and water extracts of the leaves of Bidens pilosa and Chenopodium album. Acta Pol Pharm 68: 83-92.

23 Tobinaga S, Sharma MK, Aalbersberg WG, Watanabe K, Iguchi K, et al. (2009) Isolation and identification of a potent antimalarial and antibacterial polyacetylene from Bidens pilosa. Planta Medica 75: 624-628.

24 Moshi MJ, Otieno DF, Weisheit A (2012) Ethnomedicine of the Kagera Region, north western Tanzania. Part 3: plants used in traditional medicine in Kikuku village, Muleba District. Journal of Ethnobiology and Ethnomedicine 8: 14.

25 Chifundera K (1998) Livestock diseases and the traditional medicine in the bush area, Bushi, Kivu Province, Democratic Republic of Congo. African Study Monographs 19: 13-33.

26 Shekhar TC, Anju G (2012) A Comprehensive Review on Ageratum conyzoides Linn. (Goat weed). Int J Pharm Phytopharmacol Res 1: 391-395.

27 Ming LC (1999) Ageratum conyzoides: A tropical source of medicinal and agricultural products. In: Janick J (ed.), Perspectives on new crops and new uses. ASHS Press, Alexandria, VA. pp: 469-473.

28 Klauss V, Adala HS (1994) Traditional herbal eye medicine in Kenya. World Health Forum 15: 138-143.

29 Abrus precatorius L. - Rosary pea Jequirity - Fabaceae.

30 Bobbarala V, Vadlapudi V (2009) Abrus precatorius L. Seed extracts antimicrobial properties against clinically important bacteria. Int J Pharm Tech Res 1: 1115-1118.

31 Watanabe T, Rajbhandari KR, Malla K, Yahara S (2005) A Hand Book of Medicinal. Vol. III. Council of Scientific and Industrial Research (CSIR), New Delhi, India.

32 Rajeh MA, Zuraini Z, Sasidharan S, Latha LY, Amutha S (2010) Assessment of Euphorbia hirta L. leaf, flower, stem and root extracts for their antibacterial and antifungal activity and brine shrimp lethality. Molecules 15: 6008-6018.

33 Gyuris A, Szlávik L, Minárovits J, Vasas A, Molnár J, et al. (2009) Antiviral activities of extracts of Euphorbia hirta L. against HIV-1, HIV2 and SIVmac251. In vivo 23: 429-432.

34 Heyne K (1987) The useful Indonesian plants. Research and Development Agency, Ministry of Forestry, Jakarta, Indonesia.

35 Oyen LPA (2011) Ficus natalensis Hochst. [Online] Record from PROTA4U. Brink M \& Achigan-Dako EG (Eds). PROTA (Plant Resources of Tropical Africa/Ressources végétales de l'Afrique tropicale), Wageningen, The Netherlands. 
36 Bahari B (2012) The health benefits of red palm oil. Available online from: http://www.btimes.com.my/Current_News/BTIMES/ articles/20121207000222/Article

37 (2015) Ultimate Guide to Herbal Oils. Available online on: http:// articles.mercola.com/herbal-oils/palm-oil.aspx.

38 Moghadamtousi SZ, Goh BH, Chan CK, Shabab T, Kadir HA (2013) Biological Activities and Phytochemicals of Swietenia macrophylla King. Molecules 18: 10465-10483.

39 Wiliams CJ (2012) Medicinal plants of Australia. Plants, Portion and Poisons. Rosenburg Publishing Pvt. Ltd.

40 (2015) Tomato Benefits. Available online on: http://www.healthgalaxy.com/Tomato-benefits.html.

41 (2015) Remedies of bags under the eyes, home remedies for dark circles under the eyes. Available online on: http://www.botanicalonline.com/bagsundereyesremedies.htm

42 Kenny OM, McCarthy CM, Brunton NP, Hossain MB, Rai DK, et al. (2013) Anti-inflammatory properties of potato glycoalkaloids in stimulated Jurkat and Raw 264.7 mouse macrophages. Life Science 92: 775-782.

43 Patel J, Tripathi P, Sharma V, Chauhan NS, Dixit VK (2011) Phyllanthus amarus: ethnomedicinal uses, phytochemistry and pharmacology: a review. Journal of Ethnopharmacology 138: 286-313.

44 Gelfand M, Mavi S, Drummond RB, Ndemera B (1985) The Traditional Medicinal Practitioner in Zimbabwe: His Principles of Practice and Pharmacopeoia. Mambo, Gweru.

45 Baerts M, Lehmann J (1989) Guérisseurs et plantes médicinales de la région des crêtes Zaïre-Nil au Burundi. Musée royal de l'Afrique centrale, Tervuren, Belgique. Ann Sc Eco 18: 214.

46 Ghosh L, Gayen JR, Sinha S, Pal S, Pal M, et al. (2001) Antibacterial efficacy of Rumex nepalensis Spreng roots. J Phytother Res 17: 558-559.
47 El-Mekkawy S, Meselhy MR, Kusumoto IT, Kadota S, Hattori M, et al. (1995) Inhibitory effects of Egyptian folk medicines on human immunodeficiency virus (HIV) reverse transcriptase. Chem Pharm Bull 43: 641-648.

48 Ogundare AO (2011) Antibacterial properties of the leaf extracts of Vernonia amygdalina, Ocimum gratissimum, Corchorous olitorius and Manihot palmate. Journal of Microbiology and Antimicrobials 3: 77-86.

49 Oboh FOJ, Masodje H (2009) Nutritional and Antimicrobial Properties of Vernonia amygdalina Leaves. International Journal of Biomedical Sciences and Health 5: 51-56.

50 Baba I (2005) The red eye - first aid at the primary level. Community Eye Health 18: 70-72.

51 Andrea (2011) Natural Treatment of Conjunctivitis aka Pink Eye. Available on: http://frugallysustainable.com/2011/10/naturaltreatment-of-conjunctivitis-aka/

52 Kagashe GAB, Msela B (2012) Self Medication among patients seen at Ophthamology Clinics at four hospitals in Dar es Salaam, Tanzania. IOSR Journal of Pharmacy 2: 21-25.

53 Foster A, Johnson GJ (1994) Traditional eye medicine: good or bad news? British Journal Ophthalmology 78: 807.

54 Kråmer I, Haber M, Duis A (2002) Formulation Requirements for the Ophthalmic Use of Antiseptics. In Behrens-Baumann (Ed.), Antiseptic Prophylaxis and Therapy in Ocular Infections. Principles, Clinical Practice, and Infection Control. Switserland: Karger 33: 85-94.

55 Dubow B (2015) How to handle common eye injury. Available online on: http://www.allaboutvision.com/conditions/eye-injuries.htm.

56 Ayanniyi AA (2009) A 39-year old man with blindness following the application of raw cassava extract to the eye. Digital Journal of ophthalmology. p: 15. 